\title{
Review
}

Pathobiology

\section{Turning Skyscrapers into Town Houses: Insights into Barrett's Esophagus}

\author{
Theresa D. Ahrens ${ }^{a, b} \quad$ Lisa Lutz $^{a} \quad$ Silke Lassmann ${ }^{a, c-e} \quad$ Martin Werner ${ }^{a, d, e}$ \\ ${ }^{a}$ Institute for Surgical Pathology, Medical Center and Faculty of Medicine, ${ }^{b}$ Faculty of Biology and ${ }^{\mathrm{C} B I O S S}$ Centre \\ for Biological Signalling Studies, University of Freiburg, and ${ }^{d}$ Comprehensive Cancer Center Freiburg, Freiburg, and \\ e German Cancer Consortium (DKTK) and German Cancer Research Center (DKFZ), Heidelberg, Germany
}

\section{Key Words}

Barrett's esophagus · Metaplasia · Transdifferentiation ·

Transcommitment $\cdot$ Epigenetics

\section{Abstract}

Barrett's esophagus (BE) is defined as metaplasia of the esophageal squamous epithelium with multiple cell layers into a single layer of intestinal columnar epithelial cells - or, in other words, skyscrapers are turned into town houses. The underlying pathomechanism(s) and the cell of origin of $\mathrm{BE}$ lesions have not been defined yet. However, four potential hypotheses for BE development have been suggested. The morphological changes during $\mathrm{BE}$ development are associated with rather well-described aberrant gene/protein expression patterns. However, the potential key regulators of this conversion process are still unclear. The process of metaplastic conversion is difficult to monitor in a spatiotemporal manner in vitro, and robust models are lacking. There is therefore a need for novel experimental systems. This review focuses on potential key regulators, microenvironmental influences, epigenetic alterations and experimental research systems related to $\mathrm{BE}$.

(c) 2016 S. Karger AG, Basel

\section{Introduction}

Barrett's esophagus (BE) develops via replacement of the esophageal squamous epithelium with an intestinal columnar epithelium, representing a metaplastic lesion (fig. 1a). This describes several major changes in histological architecture in just a few words. An analogy may help the understanding of the fundamental conversion: the normal esophageal epithelium is a stratified squamous epithelium with multiple cell layers, comparable to 'skyscrapers' with different floors. In contrast, the epithelium of BE consists of a unilayered, columnar epithelium or 'at-grade town houses' (fig. 1b). During BE development, a great departure from the biological construction plan occurs, with skyscrapers being turned into town houses. BE lesions may then proceed via dysplastic changes to Barrett's adenocarcinomas (BACs; fig. 1a).

Histological evidence of goblet cells in endoscopic biopsies is essential for $\mathrm{BE}$ diagnosis in most countries, although the classification of $\mathrm{BE}$ is different in Japan and Great Britain [1,2], where the presence of metaplastic columnar epithelium is sufficient for the diagnosis of BE.

\section{KARGER}

(c) 2016 S. Karger AG, Basel
Prof. Martin Werner, MD

Institute for Surgical Pathology

Department of Pathology, University Medical Center Freiburg

Breisacherstrasse 115A, DE-79106 Freiburg (Germany)

E-Mail martin.werner@uniklinik-freiburg.de 


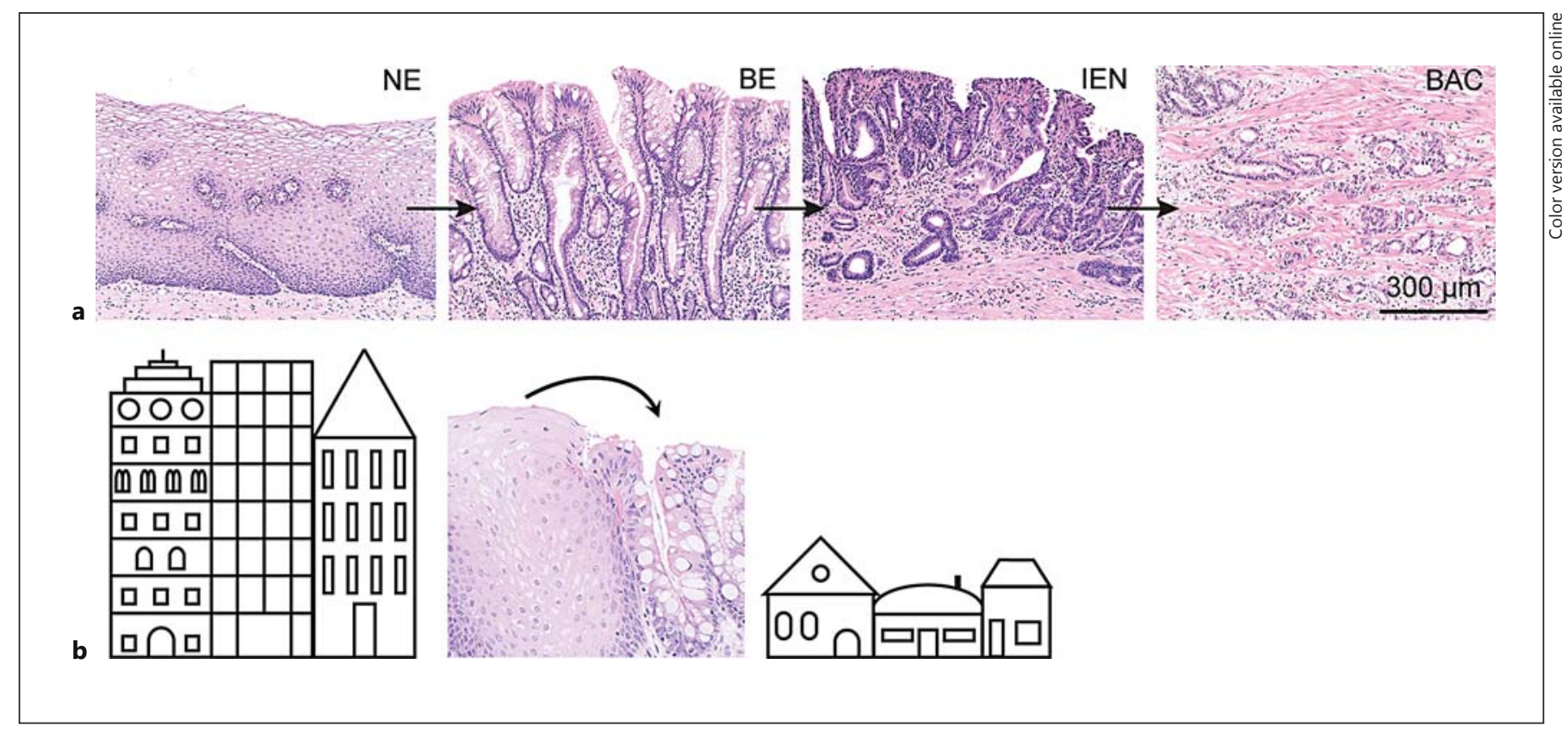

Fig. 1. a BE develops via conversion of the normal, squamous esophageal epithelium (NE) into an intestinal columnar epithelium. Some pathology societies demand the presence of goblet cells for $\mathrm{BE}$ diagnosis (see Introduction). BE lesions may proceed via dysplastic states, also called intraepithelial neoplasia (IEN), with frequent loss of goblet cells, to BAC. b These fundamental chang- es in histological architecture are possibly more understandable via an analogy: skyscrapers represent the normal esophageal squamous epithelium with its different layers, and these are then turned into little town houses via unknown mechanisms, representing the $\mathrm{BE}$ lesions with columnar epithelium.
Heterotopic columnar epithelium of cardia or fundus type, which is originally in the direct neighborhood of the esophagogastric junction, lacks goblet cells and may, according to the guidelines in Japan and Great Britain, be misinterpreted as BE.

Despite the set histological classifications for BE lesions and their grade of dysplasia [2,3], there is a remarkable interobserver variability among pathologists $[2,4]$. According to the WHO, every BE lesion should be classified into one of the following 4 categories: negative for dysplasia, indefinite for dysplasia, positive for low-grade dysplasia and positive for high-grade dysplasia $[5,6]$. The interobserver variability is most prevalent for the differentiation between low-grade dysplasia versus indefinite for dysplasia [4]. Here, the elucidation of the underlying molecular pathomechanisms may be a valuable approach to more precisely define $\mathrm{BE}$ lesions and to improve the reproducibility of the histological evaluation, especially of the dysplasia classification. For example, characteristic expression patterns of key pathomechanistic proteins could facilitate BE diagnostics and subclassification, thereby underscoring/supplementing the histological detection of (low- or high-grade) dysplasia in BE lesions, which still remains the best biomarker for the risk stratification of a risk of progression to BAC [1] and hence prognosis.

The underlying molecular pathomechanisms of $\mathrm{BE}$ development are not well elucidated. However, BAC as a potential malignant end point of $\mathrm{BE}$ shows a dramatic increase in Western countries [7]. Actually, the occurrence of $\mathrm{BE}$ lesions is one major risk factor for developing BAC, with recently reported annual conversion rates of between 0.01 and $0.22 \%$, depending mainly on the length of $\mathrm{BE}$ [8]. These annual conversion rates are clearly lower than the estimates reported 5 years ago [9]. Actually, esophageal adenocarcinomas (EACs) are a heterogeneous group of tumors, which are often localized close to the esophagogastric junction $[10,11]$.

This review focuses on recent advances in defining the cellular origin of $\mathrm{BE}$ lesions as well as the mechanisms involved, including changes in protein expression and epigenetic aspects. In addition, potential systems for $\mathrm{BE}$ 'bench-side' research will be discussed. 


\section{Four Potential Molecular Routes towards BE}

Two hypotheses for the cellular origin of BE lesions are currently in focus: 'true' trans-differentiation of the normal esophageal epithelium (route 1) or wrong differentiation of esophageal stem cells residing in the basal cell layers or in the esophageal glands, also termed 'transcommitment' (route 2) [12, 13].

Embryonic development shows that the human esophagus develops from a columnar epithelium which is replaced from the middle by rostral and caudal extension of a stratified squamous epithelium $[14,15]$. Yu et al. [16] revealed that esophageal columnar/keratin- $8^{+}$ cells differentiate via a double-positive state into squamous/keratin- $14^{+}$cells. This demonstrates the capacity of esophageal epithelial cells to undergo 'true' trans-differentiation, thus clearly supporting the trans-differentiation model (route 1). This theory was further strengthened by Mari et al. [17], who recently excluded the involvement of $\operatorname{Lgr} 5^{+}$progenitor cells from neighboring columnar intestinal epithelia in the formation of esophageal metaplasia.

The trans-commitment of esophageal stem cells with wrong differentiation (route 2 ) has not been clearly proven so far and even these stem cells themselves have not been finally defined [18]. But recent work in mice revealed that the esophageal epithelium is maintained by a distinct progenitor population [19]. The link of BE development and esophageal stem cells was recently reviewed by Barbera and Fitzgerald [20].

Furthermore, colonization by bone marrow stem cells with subsequent trans-commitment (route 3 ) for the $\mathrm{BE}$ development is under discussion $[21,22]$. In a study by Sarosi et al. [21] in 2008, female rats were lethally irradiated and transplanted with bone marrow from male rats. This allowed the use of the Y-chromosome as a marker for bone marrow cell colonization in organs. Female rats with reflux esophagitis caused by esophagojejunostomy showed areas of intestinal metaplasia. Indeed, half of the squamous epithelial cells (49.6\%) stained positive for Ychromosome by FISH, indicating the descent from the transplanted male bone marrow cells. Furthermore, the authors excluded the possibilities of the fusion of bone marrow cells and epithelial cells or invading white blood cells. This theory was further strengthened by Hutchinson et al. [22] in 2011 with a mouse model. They also detected the occurrence of cells with female karyotype within the BAC tumor in one male patient after bone marrow transplantation. This provides at least an in vivo proofof-principle for the involvement of bone marrow-derived cells in BE lesions, but it is still questionable whether these cells are causative in the development of BE.

The fourth route to BE lesions is cellular competition between esophageal squamous cells and a foreign cell linage. This older concept suggests that BE lesions may arise by replacement with columnar cells of gastric or junctional origin [23]. Indeed, a recent study on human esophageal tissues after IdU labelling revealed that cells expressing $\mathrm{Lgr} 5^{+} \mathrm{Ki}-67^{+}$residing in the middle of $\mathrm{BE}$ glands showed a bidirectional flux of cells towards the surface and into the base of the BE glands, reflecting the gland architecture of antral or pyloric mucosa of the stomach [24]. This finding points towards BE originating from the gastric epithelium. Quante et al. [25] also suggested that $\mathrm{Lgr}^{+}$cells within the cardiac mucosa are responsible for BE formation. Moreover, McDonald et al. [26] have recently suggested that $\mathrm{BE}$ lesions derive from cardiac stem cells by revisiting the morphological architecture of human Barrett mucosa. Further, cellular competition could also be mediated by embryonic residual cells. A study on a murine p63-null model suggests that residual $\mathrm{Car}^{+}{ }^{+}$embryonic cells give rise to metaplastic esophageal epithelium by cellular competition, independent of a trans-commitment mechanism [27].

In summary, there are currently 4 potential routes for the development of BE (fig. 2): (1) trans-differentiation of the esophageal epithelium, (2) trans-commitment by wrong differentiation of stem cells either of the esophageal epithelium itself or of the submucosal glands, (3) colonization by bone marrow-derived stem cells and (4) cellular competition, e.g. by the upward progression of cardiac stem cells. Routes (2) and (3) may represent 'similar' mechanisms, with different origins of the stem cells involved, i.e. from the esophageal niche itself or from the bone marrow, but both these stem cell populations show a dramatic switch in their differentiation programs. Indeed, these 4 routes are maybe not mutually exclusive and $\mathrm{BE}$ pathogenesis may also vary, depending on the background of the individual patient.

\section{Expression Pattern Changes Associated with BE Lesions}

Not surprisingly, the morphologic conversion of squamous epithelial cells into intestinal columnar epithelial cells during BE development is reflected by changes in gene and protein expression patterns (fig. 3, summary).

This refers especially to proteins associated with cellular differentiation or cell-to-cell interactions. For exam- 


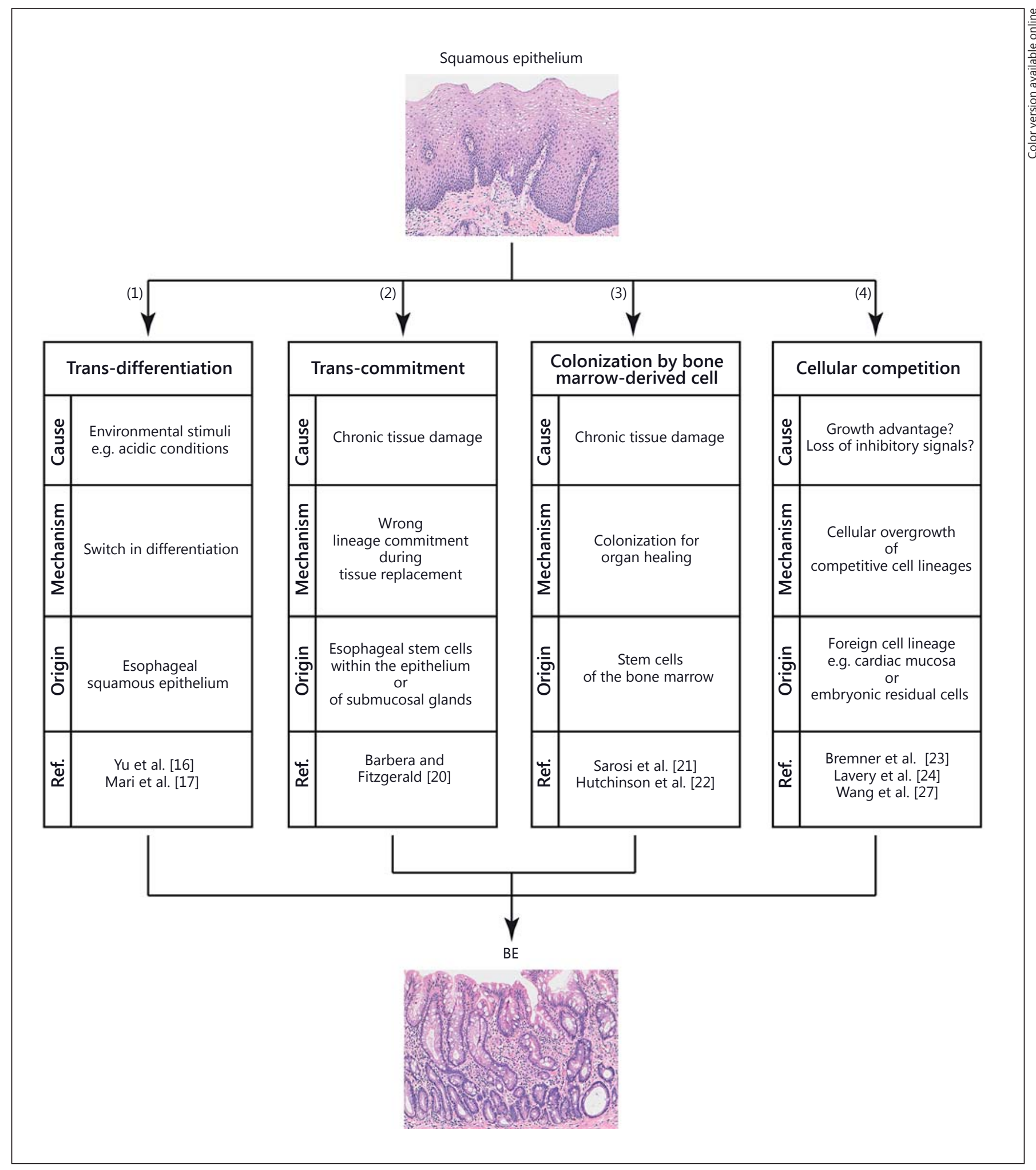

Fig. 2. Potential routes to the development of BE. The exact mechanisms by which the normal esophageal squamous epithelium is turned into BE have not been well elucidated. However, 4 potential development routes have been described so far: the trans-differen- tiation (1) and trans-commitment of stem cells of either esophageal (2) or bone marrow origin (3) and cellular competition (4). Each of this hypotheses may explain the development of BE lesions and may depend on the background of the individual patient. 


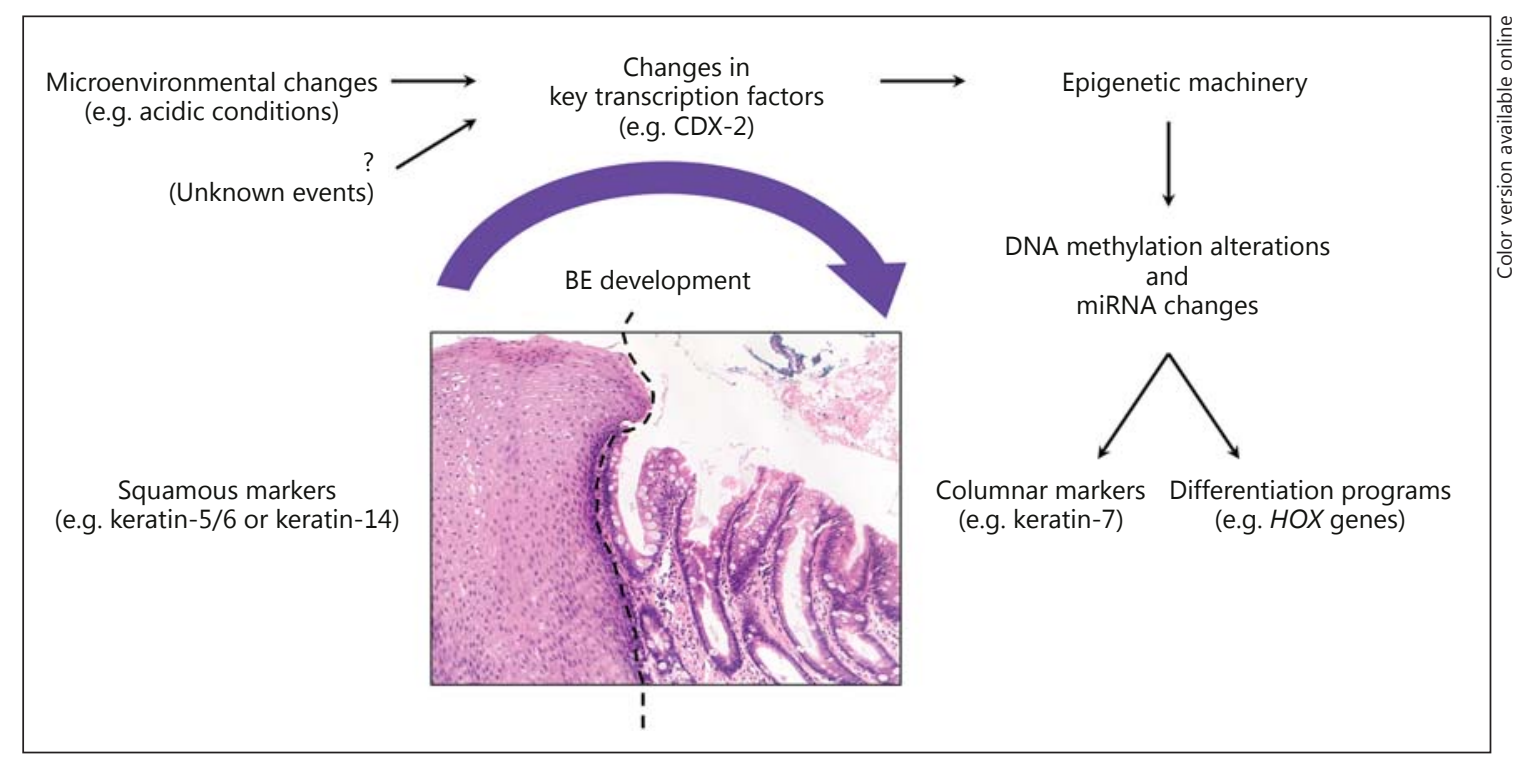

Fig. 3. Changes during the development of BE. The exact events initiating the development of BE are still largely unknown. However, changes in the microenvironment such as increased acid levels due to reflux or chemokine expression are known to initiate BE lesions. Moreover, key transcription factors like CDX-2 are up- regulated, which then mediates complex changes in the epigenetic landscape including promoter demethylation or miRNA alterations. This leads, finally, to gene/protein expression changes associated with differentiation programs and the subsequent upregulation of columnar markers (e.g. keratin-7). ple, BE lesions show a switch of cytokeratin expression from squamous (e.g. keratin-5/6 or keratin-14) towards columnar markers like keratin-7, keratin- 8 or keratin-18 [28]. Moreover, claudin-3 and claudin- 4 are specifically upregulated in $\mathrm{BE}$ lesions compared to normal esophageal epithelia or esophageal squamous cell carcinoma (ESCC) [29]. Isoform 2 of claudin-18 is also upregulated in $\mathrm{BE}$ and may foster resistance to acidic conditions [30].

Mucin expression changes during BE development. Normal esophagus shows MUC1 and MUC4 expression in squamous epithelial cells as well as MUC5B expression in the esophageal glands [31]. In contrast, BE lesions show upregulation of the gastric mucins MUC5A and MUC6 [31,32]. Here, MUC5A is expressed in the surface epithelium and MUC6 expression is localized to the deeper glands, resembling an expression pattern seen in the gastric mucosa [33].

MUC2 is expressed specifically in goblet cells [34, 35]. Indeed, MUC2 is directly linked to goblet cell differentiation since $\mathrm{Muc2}^{-/-}$mice show a lack of goblet cells in the intestine [36]. Caudal-type homeobox protein 2 (CDX-2) is known to activate the MUC2 promoter and is also upregulated during $\mathrm{BE}$ development $[37,38]$. Therefore, CDX-2 upregulation may be interconnected with goblet cell differentiation via MUC2 expression during BE de- velopment. Indeed, CDX-2 overexpression in vitro increases MUC2 mRNA and protein expression [39, 40]. Besides, positive MUC2 expression in non-goblet squamous epithelial cells has been shown to be valuable for detecting goblet cells in $\mathrm{BE}$ tissue sections of endoscopic biopsies [34]. Thus, the assessment of MUC2 may be useful for diagnostic purposes since the distribution of goblet cells is patchy in some cases.

Moreover, BACs segregate into gastric-type tumors with MUC5A positivity and intestinal-type tumors with MUC2 positivity; Szachnowicz et al. [41] suggested that these 2 BAC subtypes may reflect 2 different potential cells of origin being involved in BAC carcinogenesis.

\section{CDX-2 as a Potential Key Regulator during BE Development}

The key regulators involved in $\mathrm{BE}$ development have not yet been determined in detail. One suggested key regulator is CDX-2, which is known to be involved in intestinal differentiation and proliferation $[42,43]$. Indeed, BE lesions show increased CDX-2 levels compared to normal esophageal squamous epithelia [38, 44, 45], but CDX-2 levels decrease again with progression to BAC $[44,45]$. 
Table 1. Putative key regulators involved in the development of BE

\begin{tabular}{ll}
\hline Regulator & Finding \\
\hline FOXA2 & $\begin{array}{l}\text { increased expression in BE and overexpression in } \\
\text { esophageal epithelial cells induced MUC2 [56] }\end{array}$ \\
\hline CDX-2 & $\begin{array}{l}\text { upregulated in BE tissues [38, 44, 45], complex } \\
\text { formation with SMAD4 [17] and induction of } \\
\text { intestinal markers [39] }\end{array}$ \\
\hline GATA6 & $\begin{array}{l}\text { increased expression in BE [57], and } \\
\text { overexpression, together with FGFR2IIb, } \\
\text { increased the anchorage-independent growth [58] }\end{array}$ \\
\hline HOXB genes & $\begin{array}{l}\text { higher levels in BE samples and overexpression } \\
\text { increased columnar markers [61] }\end{array}$ \\
\hline TLR4 & $\begin{array}{l}\text { overexpressed in BE, and activation led to NF- } \mathrm{kB} \\
\text { signaling [62] }\end{array}$ \\
\hline
\end{tabular}

In addition, 3 single-nucleotide polymorphisms of the CDX2 gene (rs4769585 and rs3812863) have been associated with a higher risk for $\mathrm{BE}[46,47]$.

Identification of CDX-2 target genes by a study on overexpression in intestinal rat cells linked CDX-2 to the Notch pathway [48]; this has been also observed in human BE tissue specimens [32]. ChIP-Seq analyses in the colorectal cancer cell line Caco-2 linked CDX-2 binding to target genes or their enhancers, involved in differentiation and transcriptional regulation [49]. Interestingly, enhancers are thought to define cell-specific transcription patterns [50]. Hence, the notion that CDX-2 overexpression leads to reshaping of enhancer activity appears feasible.

However, overexpression of CDX-2 in vitro [51] and in vivo [52] failed to induce complete intestinalization of normal esophageal squamous epithelial cells. Overexpression of CDX-2 in non-neoplastic esophageal epithelial Het-1A cells was found more successful in the induction of intestinalization [39] when compared to a similar study on EPC-hTERT cells [51]. Het-1A cells are immortalized by SV40 T-antigen [53], whereas EPC-hTERT cells are immortalized by hTERT [54]. hTERT does not disrupt cellular signaling compared to the immortalization by the SV40 T-antigen, which impedes the p53 and $\mathrm{Rb}$ pathways [55]. This may illustrate that BE development is implemented in complex cellular signaling networks and that overexpression of a single transcription factor may not be sufficient for intestinalization. Indeed, Mari et al. [17] recently showed that the complex formation of CDX-2 with SMAD4 is essential for the induction of intestinalization.
New and additionally regulators have therefore to be considered. For example, BE tissue samples show higher FOXA2 expression than normal esophageal squamous epithelia and, indeed, FOXA2 overexpression in esophageal squamous NES-B3T cells results in MUC2 expression [56]. Similarly, GATA6 expression is also increased in BE lesions compared to normal esophageal epithelium [57] and the overexpression of GATA6, together with FGFR2IIb, has been found to increase the anchorage-independent growth of the BE cell line CP-A [58]. Conflicting results show that upregulated miR-145 in BE lesions downregulates GATA6 and inhibits proliferation in nonneoplastic esophageal Het-1A cells [59]. Interestingly, it is thought that the binding of FOXA and GATA factors, which are pioneer transcription factors, opens up and reshapes closed (hetero)chromatin [60]. Hence, (over)expression of FOXA2 or GATA6 might induce embryonic development programs, leading to the rebuilding of the normal esophageal tissue architecture.

Further, $H O X B$ genes are also overexpressed in $\mathrm{BE}$ and have been shown to influence the expression of columnar cell markers like MUC2 or keratin-18 without influencing CDX-2 levels [61]. Expression of Toll-like receptor 4 (TLR4) also increases during BE development and its activation via lipopolysaccharide increases NF- $\kappa B$ activation and COX-2 expression [62]. Hence, several potential key regulators have been discovered in (over)expression studies on BE tissues/cells (table 1), but the functional consequences are mostly unknown and need further characterization.

\section{Microenvironmental Changes during BE Development}

For the development of BE lesions, chronic tissue damage from gastroesophageal reflux disease (GERD) seems to be critical and is the highest risk factor for $\mathrm{BE}$ [63]. Indeed, GERD leads to an aggressive environment with acidic conditions and reactive oxygen species [64], which may cause chronic inflammation. BE biopsies show an accumulation of oxidative DNA damage with subsequent induction of telomerase activity and TP53 mutations [65]. It has thus been discussed whether BE development is a protective mechanism in the normal esophageal epithelium that establishes resistance to an acidic environment, e.g. by the induction of claudin- 18 expression [30].

In vitro, acidic and/or bile acid treatment of non-neoplastic Het-1A cells results in increased CDX-2 expres- 
sion via promoter demethylation [39]. Moreover, acidic treatment of Het-1A cells has been found to activate Hedgehog signaling with subsequent bone morphogenetic protein 4 (BMP4) expression and intestinalization [66]. Hence, microenvironmental stresses have been linked to epigenetic changes and the upregulation of the known $\mathrm{BE}$ key regulator, CDX-2.

$\mathrm{BE}$ is often associated with inflammatory processes, as reviewed by Poehlmann et al. [67]. The proinflammatory genotype based on the IL-12B C-allele with an associated higher expression of IL-12p70 predisposes for BE development [68]. Indeed, BE patients show an increased histopathological degree of inflammation from distal to proximal, accompanied by increased expression of cytokines like interleukin (IL)-1 $\beta$, IL-10 and IL-4 [69]. Interestingly, IL-1 $\beta$ expression is markedly enhanced upon coculture of normal squamous epithelial and BE cells [69], suggesting an interaction of these two cell types. IL-10 expression is restricted to the inflammatory cells in nondysplastic $\mathrm{BE}$ lesions, but can also be observed in the $\mathrm{BE}$ cells themselves in dysplastic BE lesions [69]. Importantly, IL-10 as anti-inflammatory cytokine is thought to be involved in cancer immune evasion [70], and so increased IL-10 expression might contribute to neoplastic progression to BAC. In vitro IL-4 treatment of normal human esophageal epithelial cells increases expression of columnar markers like keratin-8, with the concomitant downregulation of squamous markers like keratin-13 or involucrin [71], indicating a potential trans-differentiation into a BE-like state. Moreover, BE lesions show higher levels of IL-6 [72] and, indeed, transformed BE cells start the secretion of IL- 6 in vitro with the autocrine activation of the STAT3 axis, mediating resistance to apoptosis [73].

Several chemokines of the chr4q21 chemokine cluster are upregulated in dysplastic BE lesions via promoter demethylation [74], suggesting that epigenetic changes are involved in the cytokine changes observed during $\mathrm{BE}$ development.

A stromal microenvironment may also contribute to BE development. Saadi et al. [75] showed that expression profiles of the stromal components (after laser microdissection) are sufficient to discriminate between BE without dysplasia, BE with dysplasia and BAC. Moreover, increased expression of stromal genes, including TMEPAI and $J M Y$, are significantly associated with a worse prognosis [75]. Stromal cells in BE tissue specimens also show increased BMP4 expression [66, 76]. Interestingly BMP4 stimulation is essential to induce MUC2 expression in CDX-2-overexpressing cells in vitro [17].

Insights into Barrett's Esophagus
Thus, alterations of cytokine expression either in the stromal components or in the BE cells themselves might contribute to the cellular changes and even to neoplastic progression.

\section{Epigenetic Alterations of BE Lesions}

Since epigenetic alterations are described for BE lesions, it seems likely that epigenetic alterations are involved in BE development. Epigenetic mechanisms include noncoding RNA metabolism, DNA methylation and histone modifications. Indeed, many epigenetic aberrations have been described for $\mathrm{BE}$ lesions as well as for the progression from $\mathrm{BE}$ to $\mathrm{BAC}$ [77-79].

Changes in miRs have been extensively studied for $\mathrm{BE}$ lesions and its progression to BAC $[77,78]$. This revealed, for instance, the progressive upregulation of miR-21 [80] or miR-221/222 [81]. Indeed, miR-221/222 has been shown to interact with the $3^{\prime}$ UTR of the p27Kip1 mRNA, causing the proteasomal degradation of CDX-2 [81]. This partially explains the progressive downregulation of CDX-2 during BAC progression. Moreover, inhibitors of miR-221/222 impair tumor growth in xenografts [81]. Matsuzaki et al. [81] demonstrated that miR-221 and miR-222 are upregulated by bile acids via activation of the bile acid receptor.

DNA methylation [79] has also been a focus of BE research. For example, DNA hypermethylation frequently downregulates $C D K N 2 A$ early in $\mathrm{BE}$ development and is also associated with a higher risk for progression to $\mathrm{BAC}$ [82-84]. Other markers for risk stratification of a progression to $\mathrm{BAC}$ are the silencing of TIMP 3 or TERT by DNA hypermethylation [85]. However, in general, DNA hypomethylation seems to be more common in BE lesions and leads to the expression of genes associated with differentiation programs, like the HOX genes, or cellular proliferation [86]. Interestingly, in vitro and in vivo studies show that DNA demethylation by 5 -azacytidine or decitabine enhances intestinalization effects after CDX-2 overexpression $[51,52]$. This may support the idea that DNA methylation changes are involved in BE development. However, it is still unclear what causes such changes in vivo. Besides, the assessment of DNA methylation in a subset of 8 genes ( $p 16$, RUNX3, HPP1, NELL1, TAC1, SST, AKAP12 and CDH13) may be useful for the risk stratification of neoplastic progression [87]. As an adjunct to histopathology, this may be helpful in improving patient selection for surveillance endoscopy, since annual conversion rates of $\mathrm{BE}$ are relatively low $[8,9]$, and it has

Pathobiology 2017;84:87-98

DOI: $10.1159 / 000447779$ 
Table 2. Overview of established BE cell lines

\begin{tabular}{|c|c|c|c|c|c|}
\hline CP-A & KR-42421 [89] & nondysplastic BE [88] & WT (exon 5-8) [88] & $\operatorname{del}(\mathrm{C} 5.1)[88]$ & $50[88]$ \\
\hline CP-B & CP-52731 [89] & H-IEN [88] & $\mathrm{A} 175 \mathrm{H}[88]$ & L97G [88] & $44[88]$ \\
\hline $\mathrm{CP}-\mathrm{C}$ & CP-94251 [89] & H-IEN [88] & A248T [88] & WT [88] & $44[88]$ \\
\hline CP-D & CP-18821 [89] & H-IEN [88] & exon $8 / 302$ frameshift [88] & $\operatorname{del}(\mathrm{C} 5.1)[88]$ & $41[88]$ \\
\hline BAR-T & - & nondysplastic BE [90] & $\begin{array}{l}\text { functional intact, } \\
\text { not sequenced [90] }\end{array}$ & $\begin{array}{l}\text { functional intact, } \\
\text { not sequenced [90] }\end{array}$ & $46[90]$ \\
\hline BAR-T10 & - & nondysplastic BE [91] & - & - & - \\
\hline
\end{tabular}

$\mathrm{H}$-IEN = High-grade intraepithelial neoplasia.

not yet been defined which patients benefit from regular surveillance [13].

Histone modifications have not been studied in cases of BE or BAC, but predominantly in ESCC cases [77]. However, HOXB genes show a loss of the repressive $\mathrm{H} 3 \mathrm{~K} 27 \mathrm{me} 3$ marker and an increase in 2 activating histone marks (H3K4me3 and global histone $\mathrm{H} 3$ acetylation) in BAC when compared to normal esophageal squamous epithelium [61]. Clearly, histone modifications need to be further investigated to clarify their role in BE development.

\section{Experimental Systems for BE Research}

Cell line systems would theoretically provide 'unlimited material' for in vitro studies. Currently, there are only 2 immortalized cell line sets available: the CP-A/CP-B/ CP-C and CP-D cell lines and the BAR-T cell lines, which have all been immortalized by hTERT [88-91]. Table 2 summarizes the characteristics of these established BE cell lines. These BE cell lines provide a useful tool for BE research. Analysis of acid treatment in BAR-T cells revealed an increase in reactive oxygen species, DNA damage and Chk2 activation, proposing acid to be a potential carcinogen $[64,91]$. Importantly, BAR-T cells have also been used to engineer sub-cell lines with the knockdown of p53 and/ or introducing oncogenic $\mathrm{H}-\mathrm{Ras}^{\mathrm{G} 12 \mathrm{~V}}$ to recapitulate the different stages of BE progression to BAC [92]. Bus et al. [93] recently summarized the findings on the cellular effects of bile and/or acid treatments in BE cell lines as well as in non-neoplastic esophageal cell lines. Primary cell cultures of BE-derived cells could be cultivated for at least 17-29 population-doublings before reaching senescence [88], but these primary cell lines were then mainly used to generate the immortalized CP cell lines [89].
Classic cell culture approaches with monolayer systems may not be ideal to study the complex 3-dimensional changes in tissue architecture during BE development. Indeed, organoid cultures of primary BE patient material were successful [94], providing a 3-dimensional in vitro model. This was also applied to mouse esophageal epithelial cells, showing comparable differentiation of such organoids in vitro and the esophageal squamous epithelium in situ based on the expression patterns of cytokeratin-17 and p63 [95]. By using organoids with mouse keratinocytes in vitro, DeWard et al. [95] showed that Sox2, Wnt and BMP signaling regulated the self-renewal of putative esophageal stem cells. However, organoids have not been applied to model BE development.

Monolayer cell cultures as well as organoid cultures are missing stromal interactions, which have been reported to influence $\mathrm{BE}$ development as mentioned above. Hence, organotypic cultures (OTCs) using esophageal fibroblasts in the matrix layer may be more suitable to mimic interaction with the microenvironment. OTCs have been established for non-neoplastic esophageal epithelial cells and BE cell lines [96]. However, Kosoff et al. [96] reported invasive growth of the CP-A cells in OTC. Thus, established BE cell lines may not mirror the noninvasive parental $\mathrm{BE}$ lesions (maybe through immortalization) and this has to be carefully considered when designing studies and interpreting data. OTCs of non-neoplastic Het-1A cells have been used to gain first insights into trans-differentiation processes, showing that $c-m y c$ and CDX1 coexpression induce MUC5A expression [97]. Hence, in view of the complex cellular involvement, difficulties still exist in modelling the 4 routes to BE development, and we await the further exploration of this system.

BE mouse models are rare and are mostly based on surgical approaches. Such approaches are very laborious 
and can be ineffective. For example, in some models, only $7 \%$ of the mice developed BE lesions with no progression to BAC [98]. However, other surgical mouse models showed higher rates of $\mathrm{BE}$ lesions and progression to $\mathrm{BAC}$ in $55 \%$ of mice after 5 months [99].

A genetic mouse model for BE/BAC was developed by the overexpression of human IL- $\beta 1$, resulting in the L2IL-1 $\beta$ mouse [25]. These mice developed Barrett-like metaplasia in the esophagus, resembling human BE lesions, and around 20\% developed high-grade dysplasia or even intramucosal BAC at around 20 months of age. A transgenic mouse model of CDX-2 (over)expression in the esophageal epithelium under control of the keratin-14 promoter failed to induce complete intestinalization and showed only minor morphologic changes for the basal cell compartment [52].

Importantly, surgical and genetic mouse models have the drawback of histological differences to the situation in humans, e.g. the lack of submucosal glands [100]. This may exclude some potential human BE development routes a priori, like the trans-commitment of stem cells derived from esophageal glands.

For gaining insights in some side aspects of BE development, an alternative could be virtual/mathematical computer models which lack, of course, the complexity of biological networks/microenvironments. However, they do allow the modelling of the evolutionary processes during cancer initiation, like cellular competition due to mutations, leading to a higher mutational rate or growth advantages (e.g. the cumulative probability of mitosis in single cells) [101]. Indeed, virtual esophageal cancer models have been the first to show that the generation of a genetically unstable cell clone increases the probability of progression to esophageal cancer, which has been partially demonstrated in a BE patient cohort $[101,102]$.

\section{Conclusion}

The Barrett mucosa is a striking and complex pathological lesion, arising from a switch in cellular differentiation. The exact molecular pathomechanisms leading to a Barrett mucosa are only poorly understood. But 4 potential routes to the formation of $\mathrm{BE}$ lesions have been suggested, including trans-differentiation, trans-commitment of esophageal stem cells, colonization by bone marrow-derived cells and cellular competition. Clearly, future work is needed to clarify these hypotheses, taking into consideration the individual patient's background and to establish whether the pathomechanisms are mutually exclusive.

Moreover, the key drivers of $\mathrm{BE}$ development are largely unknown. So far, experimental overexpression of the potential morphology/differentiation-associated regulatory protein CDX-2 shows only limited effects, and thus further key regulators for the induction of intestinalization have to be identified. For example, the pioneer transcription factors, such as FOXA2 and GATA6, have been recently reported to be overexpressed in BE lesions. Investigation of their functional consequences appears to be the next experimental step forward.

Clearly, the microenvironment is also involved in $\mathrm{BE}$ development. This has already been shown for stromal components and for the metaplastic cells themselves. Altered expression of cytokines might contribute to transdifferentiation (e.g. IL-4) or even neoplastic progression (e.g. IL-10).

Future concepts and experimental strategies should include the investigation of epigenetic alterations, especially histone modifications, which have not been studied so far. Therefore, translational approaches, based on (1) prospective biomarker studies which account for morphological and molecular characteristics of tissue specimens, (2) in vitro experiments and (3) new robust animal models, will facilitate novel insights into the causes and consequences of $\mathrm{BE}$.

\section{Acknowledgements}

This work was supported in part by the Deutsche Forschungsgemeinschaft (SFB992 grant C3 to S.L.; grant SFB850 C5 to S.L. and M.W.) and by the Mushett Family Foundation (Chester, N.J., USA; grant to S.L. and M.W.).

\section{References}

$$
\begin{aligned}
& 1 \text { Werner M, Lassmann S: Update on Barrett } \\
& \text { esophagus and Barrett carcinoma. Pathologe } \\
& \text { 2012;33(suppl 2):253-257. } \\
& 2 \text { Fléjou JF: WHO Classification of Digestive } \\
& \text { Tumors, ed 4. Ann Pathol 2011;31:S27-S31. } \\
& 3 \text { Odze RD: Barrett esophagus: histology and } \\
& \text { pathology for the clinician. Nat Rev Gastroen- } \\
& \text { terol Hepatol 2009;6:478-490. } \\
& 4 \text { Montgomery E, Bronner MP, Goldblum JR, } \\
& \text { Greenson JK, Haber MM, Hart J, Lamps LW, } \\
& \text { Lauwers GY, Lazenby AJ, Lewin DN, Robert } \\
& \text { ME, Toledano AY, Shyr Y, Washington K: } \\
& \text { Reproducibility of the diagnosis of dysplasia } \\
& \text { in Barrett esophagus: a reaffirmation. Hum } \\
& \text { Pathol 2001;32:368-378. } \\
& 5 \text { Bosman FT, Carneiro F, Hruban RH, Theise } \\
& \text { ND: WHO Classification of Tumours of the } \\
& \text { Digestive System. Lyon, IARC, 2010. }
\end{aligned}
$$


6 Schlemper RJ, Riddell RH, Kato Y, Borchard F, Cooper HS, Dawsey SM, Dixon MF, Fenoglio-Preiser CM, Flejou JF, Geboes K, Hattori T, Hirota T, Itabashi M, Iwafuchi M, Iwashita A, Kim YI, Kirchner T, Klimpfinger M, Koike M, Lauwers GY, Lewin KJ, Oberhuber G, Offner F, Price AB, Rubio CA, Shimizu M, Shimoda T, Sipponen P, Solcia E, Stolte M, Watanabe $\mathrm{H}$, Yamabe $\mathrm{H}$ : The Vienna Classification of gastrointestinal epithelial neoplasia. Gut 2000;47:251-255.

7 Cook MB, Chow WH, Devesa SS: Oesophageal cancer incidence in the United States by race, sex, and histologic type, 1977-2005. Br J Cancer 2009;101:855-859.

8 Pohl H, Pech O, Arash H, Stolte M, Manner H, May A, Kraywinkel K, Sonnenberg A, Ell $\mathrm{C}$ : Length of Barrett's oesophagus and cancer risk: implications from a large sample of patients with early oesophageal adenocarcinoma. Gut 2016;65:196-201.

9 Hvid-Jensen F, Pedersen L, Drewes AM, Sørensen HT, Funch-Jensen P: Incidence of adenocarcinoma among patients with Barrett's esophagus. N Engl J Med 2011;365:13751383.

10 Pennathur A, Gibson MK, Jobe BA, Luketich JD: Oesophageal carcinoma. Lancet 2013;381: 400-412.

11 Siewert JR, Stein HJ: Classification of adenocarcinoma of the oesophagogastric junction. Br J Surg 1998;85:1457-1459.

12 Fitzgerald RC: Molecular basis of Barrett's oesophagus and oesophageal adenocarcinoma. Gut 2006;55:1810-1820.

13 Spechler SJ, Souza RF: Barrett's esophagus. N Engl J Med 2014;371:836-845.

14 Menard D: Morphological studies of the developing human esophageal epithelium. Microsc Res Tech 1995;31:215-225.

15 Johns BA: Developmental changes in the oesophageal epithelium in man. J Anat 1952;86: 431-442.

16 Yu WY, Slack JM, Tosh D: Conversion of columnar to stratified squamous epithelium in the developing mouse oesophagus. Dev Biol 2005;284:157-170.

17 Mari L, Milano F, Parikh K, Straub D, Everts V, Hoeben KK, Fockens P, Buttar NS, Krishnadath KK: A pSMAD/CDX2 complex is essential for the intestinalization of epithelial metaplasia. Cell Rep 2014;7:1197-1210.

18 Croagh D, Frede J, Jones PH, Kaur P, Partensky C, Phillips WA: Esophageal stem cells and genetics/epigenetics in esophageal cancer. Ann NY Acad Sci 2014;1325:8-14.

19 Doupe DP, Alcolea MP, Roshan A, Zhang G, Klein AM, Simons BD, Jones PH: A single progenitor population switches behavior to maintain and repair esophageal epithelium. Science 2012;337:1091-1093.

20 Barbera M, Fitzgerald RC: Cellular origin of Barrett's metaplasia and oesophageal stem cells. Biochem Soc Trans 2010;38:370-373.
21 Sarosi G, Brown G, Jaiswal K, Feagins LA, Lee E, Crook TW, Souza RF, Zou YS, Shay JW, Spechler SJ: Bone marrow progenitor cells contribute to esophageal regeneration and metaplasia in a rat model of Barrett's esophagus. Dis Esophagus 2008;21:43-50.

22 Hutchinson L, Stenström B, Chen D, Piperdi B, Levey S, Lyle S, Wang TC, Houghton J: Human Barrett's adenocarcinoma of the esophagus, associated myofibroblasts, and endothelium can arise from bone marrow-derived cells after allogeneic stem cell transplant. Stem Cells Dev 2011;20:11-17.

23 Bremner CG, Lynch VP, Ellis FH Jr: Barrett's esophagus: congenital or acquired? An experimental study of esophageal mucosal regeneration in the dog. Surgery 1970;68:209-216.

24 Lavery DL, Nicholson AM, Poulsom R, Jeffery R, Hussain A, Gay LJ, Jankowski JA, Zeki SS, Barr H, Harrison R, Going J, Kadirkamanathan S, Davis P, Underwood T, Novelli MR, Rodriguez-Justo M, Shepherd N, Jansen M, Wright NA, McDonald SA: The stem cell organisation and the proliferative and gene expression profile of Barrett's epithelium replicates pyloric-type gastric glands. Gut 2014; 63:1854-1863.

25 Quante M, Bhagat G, Abrams JA, Marache F, Good P, Lee MD, Lee Y, Friedman R, Asfaha S, Dubeykovskaya Z, Mahmood U, Figueiredo JL, Kitajewski J, Shawber C, Lightdale CJ, Rustgi AK, Wang TC: Bile acid and inflammation activate gastric cardia stem cells in a mouse model of barrett-like metaplasia. Cancer Cell 2012;21:36-51.

26 McDonald SA, Lavery D, Wright NA, Jansen M: Barrett oesophagus: lessons on its origins from the lesion itself. Nat Rev Gastroenterol Hepatol 2015;12:50-60.

27 Wang X, Ouyang H, Yamamoto Y, Kumar PA, Wei TS, Dagher R, Vincent M, Lu X, Bellizzi AM, Ho KY, Crum CP, Xian W, McKeon F: Residual embryonic cells as precursors of a Barrett's-like metaplasia. Cell 2011;145:1023-1035

28 van Baal JW, Bozikas A, Pronk R, Ten Kate FJ, Milano F, Rygiel AM, Rosmolen WD, Peppelenbosch MP, Bergman JJ, Krishnadath KK: Cytokeratin and CDX-2 expression in Barrett's esophagus. Scand J Gastroenterol 2008;43:132-140.

29 Gyorffy H, Holczbauer A, Nagy P, Szabo Z, Kupcsulik P, Paska C, Papp J, Schaff Z, Kiss A: Claudin expression in Barrett's esophagus and adenocarcinoma. Virchows Arch 2005; 447:961-968.

30 Jovov B, Van Itallie CM, Shaheen NJ, Carson JL, Gambling TM, Anderson JM, Orlando RC: Claudin-18: a dominant tight junction protein in Barrett's esophagus and likely contributor to its acid resistance. Am J Physiol Gastrointest Liver Physiol 2007;293:G1106-G1113.

31 Arul GS, Moorghen M, Myerscough N, Alderson DA, Spicer RD, Corfield AP: Mucin gene expression in Barrett's oesophagus: an in situ hybridisation and immunohistochemical study. Gut 2000;47:753-761.
32 Hyland PL, Hu N, Rotunno M, Su H, Wang C, Wang L, Pfeiffer RM, Gherman B, Giffen C, Dykes C, Dawsey SM, Abnet CC, Johnson KM, Acosta RD, Young PE, Cash BD, Taylor PR: Global changes in gene expression of Barrett's esophagus compared to normal squamous esophagus and gastric cardia tissues. PLoS One 2014;9:e93219.

33 Van De Bovenkamp JH, Korteland-Van Male AM, Warson C, Buller HA, Einerhand AW, Ectors NL, Dekker J: Gastric-type mucin and TFF-peptide expression in Barrett's oesophagus is disturbed during increased expression of MUC2. Histopathology 2003;42:555-565.

34 McIntire MG, Soucy G, Vaughan TL, Shahsafaei A, Odze RD: Muc2 is a highly specific marker of goblet cell metaplasia in the distal esophagus and gastroesophageal junction. Am J Surg Pathol 2011;35:1007-1013.

35 Steininger H, Pfofe DA, Müller H, Haag-Sunjic G, Fratianu V: Expression of CDX2 and MUC2 in Barrett's mucosa. Pathol Res Pract 2005;201:573-577.

36 Velcich A, Yang W, Heyer J, Fragale A, Nicholas C, Viani S, Kucherlapati R, Lipkin M, Yang K, Augenlicht L: Colorectal cancer in mice genetically deficient in the mucin Muc2. Science 2002;295:1726-1729.

37 Mesquita P, Jonckheere N, Almeida R, Ducourouble MP, Serpa J, Silva E, Pigny P, Silva FS, Reis C, Silberg D, Van Seuningen I, David $\mathrm{L}$ : Human Muc2 mucin gene is transcriptionally regulated by CDX homeodomain proteins in gastrointestinal carcinoma cell lines. J Biol Chem 2003;278:51549-51556.

38 Eda A, Osawa H, Satoh K, Yanaka I, Kihira K, Ishino Y, Mutoh H, Sugano K: Aberrant expression of CDX2 in Barrett's epithelium and inflammatory esophageal mucosa. J Gastroenterol 2003;38:14-22.

39 Liu T, Zhang X, So CK, Wang S, Wang P, Yan L, Myers R, Chen Z, Patterson AP, Yang CS, Chen X: Regulation of CDX2 expression by promoter methylation, and effects of CDX2 transfection on morphology and gene expression of human esophageal epithelial cells. Carcinogenesis 2007;28:488-496.

40 Tamagawa Y, Ishimura N, Uno G, Yuki T, Kazumori H, Ishihara S, Amano Y, Kinoshita Y: Notch signaling pathway and CDX2 expression in the development of Barrett's esophagus. Lab Invest 2012;92:896-909.

41 Szachnowicz S, Cecconello I, Ribeiro U, Iriya K, El Ibrahim R, Takeda FR, Corbett CE, Vaz Safatle-Ribeiro A: Mucin pattern reflects the origin of the adenocarcinoma in Barrett's esophagus: a retrospective clinical and laboratorial study. World J Surg Oncol 2009;7:27.

42 Mutoh H, Hakamata Y, Sato K, Eda A, Yanaka I, Honda S, Osawa H, Kaneko Y, Sugano K: Conversion of gastric mucosa to intestinal metaplasia in CDX2-expressing transgenic mice. Biochem Biophys Res Commun 2002; 294:470-479 
43 Suh E, Chen L, Taylor J, Traber PG: A homeodomain protein related to caudal regulates intestine-specific gene transcription. Mol Cell Biol 1994;14:7340-7351.

44 Vaninetti N, Williams L, Geldenhuys L, Porter GA, Guernsey DL, Casson AG: Regulation of CDX2 expression in esophageal adenocarcinoma. Mol Carcinog 2009;48:965-974.

45 Khor TS, Alfaro EE, Ooi EM, Li Y, Srivastava A, Fujita H, Park Y, Kumarasinghe MP, Lauwers GY: Divergent expression of MUC5AC, MUC6, MUC2, CD10, and CDX-2 in dysplasia and intramucosal adenocarcinomas with intestinal and foveolar morphology: is this evidence of distinct gastric and intestinal pathways to carcinogenesis in Barrett esophagus? Am J Surg Pathol 2012;36:331-342.

46 Ren D, Zheng G, Bream S, Tevebaugh W, Shaheen NJ, Chen X: Single nucleotide polymorphisms of caudal type homeobox 1 and 2 are associated with Barrett's esophagus. Dig Dis Sci 2014;59:57-63.

47 Lassmann S, Werner M: Are caudal-type homeobox genes causal for gastro-esophageal reflux disease and Barrett's esophagus? Dig Dis Sci 2014;59:16-18.

48 Uesaka T, Kageyama N, Watanabe H: Identifying target genes regulated downstream of CDX2 by microarray analysis. J Mol Biol 2004;337:647-660.

49 Boyd M, Hansen M, Jensen TG, Perearnau A, Olsen AK, Bram LL, Bak M, Tommerup N, Olsen J, Troelsen JT: Genome-wide analysis of CDX2 binding in intestinal epithelial cells (Caco-2). J Biol Chem 2010;285:2511525125.

50 Ong CT, Corces VG: Enhancer function: new insights into the regulation of tissue-specific gene expression. Nat Rev Genet 2011;12:283293.

51 Kong J, Nakagawa H, Isariyawongse BK, Funakoshi S, Silberg DG, Rustgi AK, Lynch JP: Induction of intestinalization in human esophageal keratinocytes is a multistep process. Carcinogenesis 2009;30:122-130.

52 Kong J, Crissey MA, Funakoshi S, Kreindler JL, Lynch JP: Ectopic CDX2 expression in murine esophagus models an intermediate stage in the emergence of Barrett's esophagus. PLoS One 2011;6:e18280.

53 Stoner GD, Kaighn ME, Reddel RR, Resau JH, Bowman D, Naito Z, Matsukura N, You M, Galati AJ, Harris CC: Establishment and characterization of SV40 T-antigen immortalized human esophageal epithelial cells. Cancer Res 1991;51:365-371.

54 Harada H, Nakagawa H, Oyama K, Takaoka $\mathrm{M}$, Andl CD, Jacobmeier B, von Werder A, Enders GH, Opitz OG, Rustgi AK: Telomerase induces immortalization of human esophageal keratinocytes without p16ink4a inactivation. Mol Cancer Res 2003;1:729-738.

55 Ali SH, DeCaprio JA: Cellular transformation by SV40 large T antigen: interaction with host proteins. Semin Cancer Biol 2001;11:15-23.
56 Wang DH, Tiwari A, Kim ME, Clemons NJ, Regmi NL, Hodges WA, Berman DM, Montgomery EA, Watkins DN, Zhang X, Zhang Q, Jie C, Spechler SJ, Souza RF: Hedgehog signaling regulates FOXA2 in esophageal embryogenesis and Barrett's metaplasia. J Clin Invest 2014;124:3767-3780.

57 Pavlov K, Honing J, Meijer C, Boersma-van Ek W, Peters FT, van den Berg A, Karrenbeld A, Plukker JT, Kruyt FA, Kleibeuker JH: GATA6 expression in Barrett's oesophagus and oesophageal adenocarcinoma. Dig Liver Dis 2015;47:73-80.

58 Lin L, Bass AJ, Lockwood WW, Wang Z, Silvers AL, Thomas DG, Chang AC, Lin J, Orringer MB, Li W, Glover TW, Giordano TJ, Lam WL, Meyerson M, Beer DG: Activation of GATA binding protein 6 (GATA6) sustains oncogenic lineage-survival in esophageal adenocarcinoma. Proc Natl Acad Sci USA 2012;109:4251-4256.

59 van Baal JW, Verbeek RE, Bus P, Fassan M, Souza RF, Rugge M, ten Kate FJ, Vleggaar FP, Siersema PD: MicroRNA-145 in Barrett's oesophagus: regulating BMP4 signalling via GATA6. Gut 2013;62:664-675.

60 Zaret KS, Carroll JS: Pioneer transcription factors: establishing competence for gene expression. Genes Dev 2011;25:2227-2241.

61 di Pietro M, Lao-Sirieix P, Boyle S, Cassidy A, Castillo D, Saadi A, Eskeland R, Fitzgerald RC: Evidence for a functional role of epigenetically regulated midcluster HOXB genes in the development of Barrett esophagus. Proc Natl Acad Sci USA 2012;109:9077-9082.

62 Verbeek RE, Siersema PD, Ten Kate FJ, Fluiter K, Souza RF, Vleggaar FP, Bus P, van Baal JW: Toll-like receptor 4 activation in Barrett's esophagus results in a strong increase in COX-2 expression. J Gastroenterol 2014;49: 1121-1134.

63 Lagergren J, Bergström R, Lindgren A, Nyrén $\mathrm{O}$ : Symptomatic gastroesophageal reflux as a risk factor for esophageal adenocarcinoma. $\mathrm{N}$ Engl J Med 1999;340:825-831.

64 Zhang HY, Hormi-Carver K, Zhang X, Spechler SJ, Souza RF: In benign Barrett's epithelial cells, acid exposure generates reactive oxygen species that cause DNA double-strand breaks. Cancer Res 2009;69:9083-9089.

65 Cardin R, Piciocchi M, Tieppo C, Maddalo G, Zaninotto G, Mescoli C, Rugge M, Farinati F: Oxidative DNA damage in Barrett mucosa: correlation with telomeric dysfunction and p53 mutation. Ann Surg Oncol 2013;20(suppl 3):S583-S589.

66 Wang DH, Clemons NJ, Miyashita T, Dupuy AJ, Zhang W, Szczepny A, CorcoranSchwartz IM, Wilburn DL, Montgomery EA, Wang JS, Jenkins NA, Copeland NA, Harmon JW, Phillips WA, Watkins DN: Aberrant epithelial-mesenchymal hedgehog signaling characterizes Barrett's metaplasia. Gastroenterology 2010;138:1810-1822.
67 Poehlmann A, Kuester D, Malfertheiner P, Guenther T, Roessner A: Inflammation and Barrett's carcinogenesis. Pathol Res Pract 2012;208:269-280.

68 Moons LM, Kusters JG, van Delft JH, Kuipers EJ, Gottschalk R, Geldof H, Bode WA, Stoof J, van Vliet AH, Ketelslegers HB, Kleinjans JC, Siersema PD: A pro-inflammatory genotype predisposes to Barrett's esophagus. Carcinogenesis 2008;29:926-931.

69 Fitzgerald RC, Abdalla S, Onwuegbusi BA, Sirieix P, Saeed IT, Burnham WR, Farthing MJ: Inflammatory gradient in Barrett's oesophagus: implications for disease complications. Gut 2002;51:316-322.

70 Mumm JB, Emmerich J, Zhang X, Chan I, Wu L, Mauze S, Blaisdell S, Basham B, Dai J, Grein J, Sheppard C, Hong K, Cutler C, Turner S, LaFace D, Kleinschek M, Judo M, Ayanoglu G, Langowski J, Gu D, Paporello B, Murphy E, Sriram V, Naravula S, Desai B, Medicherla S, Seghezzi W, McClanahan T, Cannon-Carlson S, Beebe AM, Oft M: IL-10 elicits IFNgamma-dependent tumor immune surveillance. Cancer Cell 2011;20:781-796.

71 Shan J, Oshima T, Farre R, Fukui H, Watari J, Miwa H: IL-4 induces columnar-like differentiation of esophageal squamous epithelium through JAK/PI3K pathway: possible role in pathogenesis of Barrett's esophagus. Am J Physiol Gastrointest Liver Physiol 2014; 306:G641-G649.

72 Dvorakova K, Payne CM, Ramsey L, Holubec H, Sampliner R, Dominguez J, Dvorak B, Bernstein H, Bernstein C, Prasad A, Fass R, Cui $\mathrm{H}$, Garewal H: Increased expression and secretion of interleukin-6 in patients with Barrett's esophagus. Clin Cancer Res 2004; 10: 2020-2028.

73 Zhang HY, Zhang Q, Zhang X, Yu C, Huo X, Cheng E, Wang DH, Spechler SJ, Souza RF: Cancer-related inflammation and Barrett's carcinogenesis: interleukin- 6 and Stat 3 mediate apoptotic resistance in transformed Barrett's cells. Am J Physiol Gastrointest Liver Physiol 2011;300:G454-G460.

74 Alvarez H, Opalinska J, Zhou L, Sohal D, Fazzari MJ, Yu Y, Montagna C, Montgomery EA, Canto M, Dunbar KB, Wang J, Roa JC, Mo Y, Bhagat T, Ramesh KH, Cannizzaro L, Mollenhauer J, Thompson RF, Suzuki M, Meltzer SJ, Melnick A, Greally JM, Maitra A, Verma A: Widespread hypomethylation occurs early and synergizes with gene amplification during esophageal carcinogenesis. PLoS Genet 2011;7:e1001356.

75 Saadi A, Shannon NB, Lao-Sirieix P, O'Donovan M, Walker E, Clemons NJ, Hardwick JS, Zhang C, Das M, Save V, Novelli M, Balkwill F, Fitzgerald RC: Stromal genes discriminate preinvasive from invasive disease, predict outcome, and highlight inflammatory pathways in digestive cancers. Proc Natl Acad Sci USA 2010;107:2177-2182. 
76 Castillo D, Puig S, Iglesias M, Seoane A, de Bolos C, Munitiz V, Parrilla P, Comerma L, Poulsom R, Krishnadath KK, Grande L, Pera M: Activation of the BMP4 pathway and early expression of CDX2 characterize non-specialized columnar metaplasia in a human model of Barrett's esophagus. J Gastrointest Surg 2012;16:227-237; discussion 237.

77 Ahrens TD, Werner M, Lassmann S: Epigenetics in esophageal cancers. Cell Tissue Res 2014;356:643-655.

78 Kan T, Meltzer SJ: MicroRNAs in Barrett's esophagus and esophageal adenocarcinoma. Curr Opin Pharmacol 2009;9:727-732.

79 Agarwal A, Polineni R, Hussein Z, Vigoda I, Bhagat TD, Bhattacharyya S, Maitra A, Verma A: Role of epigenetic alterations in the pathogenesis of Barrett's esophagus and esophageal adenocarcinoma. Int J Clin Exp Pathol 2012;5:382-396.

$80 \mathrm{Wu}$ X, Ajani JA, Gu J, Chang DW, Tan W, Hildebrandt MA, Huang M, Wang KK, Hawk E: MicroRNA expression signatures during malignant progression from Barrett's esophagus to esophageal adenocarcinoma. Cancer Prev Res 2013;6:196-205.

81 Matsuzaki J, Suzuki H, Tsugawa H, Watanabe M, Hossain S, Arai E, Saito Y, Sekine S, Akaike T, Kanai Y, Mukaisho K, Auwerx J, Hibi T: Bile acids increase levels of microRNAs 221 and 222, leading to degradation of CDX2 during esophageal carcinogenesis. Gastroenterology 2013;145:1300-1311.

82 Bian YS, Osterheld MC, Fontolliet C, Bosman FT, Benhattar J: p16 inactivation by methylation of the CDKN2A promoter occurs early during neoplastic progression in Barrett's esophagus. Gastroenterology 2002;122:11131121.

83 Sarbia M, Geddert H, Klump B, Kiel S, Iskender E, Gabbert HE: Hypermethylation of tumor suppressor genes (p16INK4A, p14ARF and $\mathrm{APC}$ ) in adenocarcinomas of the upper gastrointestinal tract. Int J Cancer 2004;111: 224-228.

84 Schulmann K, Sterian A, Berki A, Yin J, Sato F, Xu Y, Olaru A, Wang S, Mori Y, Deacu E, Hamilton J, Kan T, Krasna MJ, Beer DG, Pepe MS, Abraham JM, Feng Z, Schmiegel W, Greenwald BD, Meltzer SJ: Inactivation of p16, RUNX3, and HPP1 occurs early in Barrett's-associated neoplastic progression and predicts progression risk. Oncogene 2005;24: $4138-4148$.
85 Clement G, Braunschweig R, Pasquier N, Bosman FT, Benhattar J: Methylation of APC, TIMP3, and TERT: a new predictive marker to distinguish Barrett's oesophagus patients at risk for malignant transformation. J Pathol 2006;208:100-107.

86 Agarwal R, Jin Z, Yang J, Mori Y, Song JH, Kumar S, Sato M, Cheng Y, Olaru AV, Abraham JM, Verma A, Meltzer SJ: Epigenomic program of Barrett's-associated neoplastic progression reveals possible involvement of insulin signaling pathways. Endocr Relat Cancer 2012;19:L5-L9.

87 Jin Z, Cheng Y, Gu W, Zheng Y, Sato F, Mori Y, Olaru AV, Paun BC, Yang J, Kan T, Ito T, Hamilton JP, Selaru FM, Agarwal R, David S, Abraham JM, Wolfsen HC, Wallace MB, Shaheen NJ, Washington K, Wang J, Canto MI, Bhattacharyya A, Nelson MA, Wagner PD, Romero Y, Wang KK, Feng Z, Sampliner RE, Meltzer SJ: A multicenter, double-blinded validation study of methylation biomarkers for progression prediction in Barrett's esophagus. Cancer Res 2009;69:4112-4115.

88 Palanca-Wessels MC, Barrett MT, Galipeau PC, Rohrer KL, Reid BJ, Rabinovitch PS: Genetic analysis of long-term Barrett's esophagus epithelial cultures exhibiting cytogenetic and ploidy abnormalities. Gastroenterology 1998;114:295-304.

89 Palanca-Wessels MC, Klingelhutz A, Reid BJ, Norwood TH, Opheim KE, Paulson TG, Feng Z, Rabinovitch PS: Extended lifespan of Barrett's esophagus epithelium transduced with the human telomerase catalytic subunit: a useful in vitro model. Carcinogenesis 2003; 24:1183-1190.

90 Jaiswal KR, Morales CP, Feagins LA, Gandia KG, Zhang X, Zhang HY, Hormi-Carver K, Shen Y, Elder F, Ramirez RD, Sarosi GA Jr, Spechler SJ, Souza RF: Characterization of telomerase-immortalized, non-neoplastic, human Barrett's cell line (BAR-T). Dis Esophagus 2007;20:256-264.

91 Zhang HY, Zhang X, Hormi-Carver K, Feagins LA, Spechler SJ, Souza RF: In nonneoplastic Barrett's epithelial cells, acid exerts early antiproliferative effects through activation of the CHK2 pathway. Cancer Res 2007; 67:8580-8587.
92 Zhang X, Yu C, Wilson K, Zhang HY, Melton SD, Huo X, Wang DH, Genta RM, Spechler SJ, Souza RF: Malignant transformation of non-neoplastic Barrett's epithelial cells through well-defined genetic manipulations. PLoS One 2010;5:e13093.

93 Bus P, Siersema PD, van Baal JW: Cell culture models for studying the development of Barrett's esophagus: a systematic review. Cell Oncol 2012;35:149-161.

94 Sato T, Stange DE, Ferrante M, Vries RG, Van Es JH, Van den Brink S, Van Houdt WJ, Pronk A, Van Gorp J, Siersema PD, Clevers $\mathrm{H}$ : Long-term expansion of epithelial organoids from human colon, adenoma, adenocarcinoma, and Barrett's epithelium. Gastroenterology 2011;141:1762-1772.

95 DeWard AD, Cramer J, Lagasse E: Cellular heterogeneity in the mouse esophagus implicates the presence of a nonquiescent epithelial stem cell population. Cell Rep 2014;9: 701-711.

96 Kosoff RE, Gardiner KL, Merlo LM, Pavlov K, Rustgi AK, Maley CC: Development and characterization of an organotypic model of Barrett's esophagus. J Cell Physiol 2012;227: 2654-2659.

97 Stairs DB, Nakagawa H, Klein-Szanto A Mitchell SD, Silberg DG, Tobias JW, Lynch JP, Rustgi AK: CDX1 and C-Myc foster the initiation of transdifferentiation of the normal esophageal squamous epithelium toward Barrett's esophagus. PLoS One 2008; 3:e3534.

98 Pham TH, Genta RM, Spechler SJ, Souza RF, Wang DH: Development and characterization of a surgical mouse model of reflux esophagitis and Barrett's esophagus. J Gastrointest Surg 2014;18:234-240; discussion 240-241.

99 Raggi M, Langer R, Feith M, Friess H, Schauer M, Theisen J: Successful evaluation of a new animal model using mice for esophageal adenocarcinoma. Langenbecks Arch Surg 2010;395:347-350.

100 Attwood SE, Harrison LA, Preston SL, Jankowski JA: Esophageal adenocarcinoma in 'mice and men': back to basics! Am J Gastroenterol 2008; 103:2367-2372.

101 Maley CC, Forrest S: Exploring the relationship between neutral and selective mutations in cancer. Artif Life 2000;6:325-345.

102 Maley CC, Galipeau PC, Li X, Sanchez CA, Paulson TG, Blount PL, Reid BJ: The combination of genetic instability and clonal expansion predicts progression to esophageal adenocarcinoma. Cancer Res 2004;64:76297633. 